
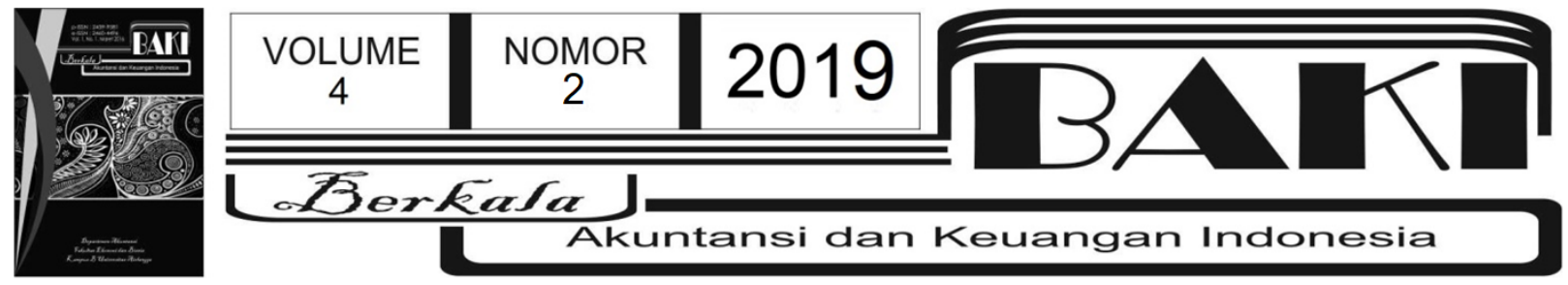

\title{
Pengaruh Net Profit Margin,Current Ratio,Firm Size,Risiko Bisnis Terhadap Struktur Modal
}

\author{
Anzella ${ }^{1,2}$ \\ Cindy Audryana ${ }^{1}$ \\ Cynthia Taslim ${ }^{1}$ \\ Esmeralda $^{1}$ \\ Firmansyah Mida ${ }^{1}$ \\ ${ }^{1}$ Universitas Prima Indonesia \\ ªnzella888@gmail.com
}

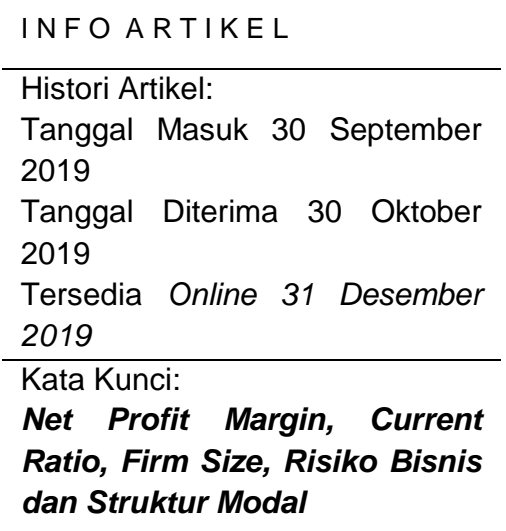

\begin{abstract}
A B S TRAK
Tujuan penelitian adalah menguji dan menganalisis pengaruh net profit margin, current ratio, firm size, risiko bisnis terhadap struktur modal pada perusahaan industri dasar dan kimia di Bursa Efek Indonesia Periode 2014-2017. Penelitian ini menggunakan pendekatan penelitian kuantitatif. Jenis penelitian yang digunakan penelitian deskriptif kuantitatif. Sifat penelitian ini adalah penelitian sebab dan akibat/kausal. Populasi penelitian ini berjumlah 67 perusahaan industri dasar dan kimia di Bursa Efek Indonesia Periode 2014-2017. Jumlah sampel penelitian sebanyak 31 perusahaan industri dasar dan kimia di Bursa Efek Indonesia Periode 2014-2017 dengan sampel pengamatan sebanyak 124 observasi pengamatan. Teknik pengumpulan data menggunakan dokumentasi dan model penelitian adalah regresi linear berganda. Hasil penelitian ini adalah Net profit margin berpengaruh dan tidak signifikan terhadap struktur modal pada perusahaan industri dasar dan kimia di Bursa Efek Indonesia Periode 2014-2017. Current ratio berpengaruh dan tidak signifikan terhadap struktur modal pada perusahaan industri dasar dan kimia di Bursa Efek Indonesia Periode 2014-2017. Firm size berpengaruh dan signifikan terhadap struktur modal pada perusahaan industri dasar dan kimia di Bursa Efek Indonesia Periode 2014-2017. Risiko bisnis berpengaruh dan signifikan terhadap struktur modal pada perusahaan industri dasar dan kimia di Bursa Efek Indonesia Periode 2014-2017. Net profit margin, current ratio, firm size, risiko bisnis berpengaruh dan signifikan terhadap struktur modal pada perusahaan industri dasar dan kimia di Bursa Efek Indonesia Periode 2014-2017.
\end{abstract}




\section{Pendahuluan}

Seiring dengan perkembangan dunia usaha, perusahaan besar maupun perusahaan kecil juga sering mengalami berbagai hambatan. Salah satunya adalah masalah pendanaan atau struktur modal perusahaan, sehingga manajer keuangan diberi kepercayaan oleh investor untuk mengelola dan menjalankan operasional usahanya.

Kebutuhan dana untuk penambahan modal perusahaan dibiayai dengan sumber dana jangka panjang seperti penerbitan saham, obligasi, dan laba ditahan. Penggunaan sumber dana jangka panjang seperti utang jangka panjang, saham, obligasi dan laba ditahan oleh perusahaan akan membentuk struktur modal. Perusahaan perlu memperhatikan beberapa faktor yang mempengaruhi struktur modal mengenai berapa jumlah hutang dan modal sendiri yang akan digunakan. Faktor yang mempengaruhi struktur modal meliputi net profit margin, current ratio, firm size, risiko bisnis terhadap struktur modal.

Purwoko menekankan masih adanya kondisi kelebihan pasokan (over supply) dari penjualan semen di Indonesia. Sehingga, penguatan yang terjadi dalam sektor industri dasar ini kemungkinan hanya bersifat jangka pendek. Tidak heran, jika kinerja emiten saham masih tertahan hinggal kuartal III ini. Hal itu tercermin dari salah satu emiten semen yakni PT Semen Indonesia Tbk (SMGR). Berdasarkan laporan keuangan perusahaan PT Semen Indonesia mengalami penurunan laba bersih sebesar 8,4 persen menjadi Rp2,92 triliun jika dibandingkan periode yang sama tahun lalu Rp3,54 triliun. Menyusutnya laba bersih tersebut sejalan dengan pendapatan usaha yang turun 0,16 persen menjadi Rp19,08 triliun sepanjang JanuariSeptember 2016.

Kebijakan mengenai struktur modal melibatkan risiko dan tingkat pengembalian atau net profit margin. Pada tahun 2016 yang terjadi penurunan pendapatan pada perusahaan Semen Indonesia ini tentu mengakibatkan terjadinya penurunan laba bersih pada tahun 2017 . Penurunan laba bersih ini dapat mengakibatkan struktur modal perusahaan menjadi rendah untuk mengimbangi hal ini perusahaan melakukan pinjaman kepada pihak eksternal perusahaan untuk menambah modal perusahaan.

Tingkat laba bersih yang menurun ini secara tidak langsung mengakibatkan current ratio perusahaan menurun untuk melakukan pembayaran hutang lancar perusahaan dengan sendirinya. Apabila current ratio perusahaan yang menurun ini dapat membawa dampak kepada perusahaan dapat menunjukkan keadaan kesulitan keuangan. Untuk itu pinjaman yang berasal dari luar perusahaan sebagian digunakan membayar kewajiban lancarnya.

Keputusan struktur modal secara langsung juga berpengaruh terhadap besarnya risiko yang ditanggung pemegang saham serta besarnya tingkat pengembalian atau tingkat keuntungan yang diharapkan. Apabila perusahaan lebih banyak menggunakan utang berarti memperbesar 
risiko yang ditanggung oleh pemegang saham dan juga memperbesar tingkat pengembalian yang diharapkan. Semua hutang atau pinjaman ini memberikan dampak pada risiko bisnis perusahaan. Semakin tinggi risiko bisnis yang terjadi di perusahaan diakibatkan tingkat hutang yang tinggi.

Pada tahun 2016 total aktiva PT. Arwana Citramulia Tbk sebesar Rp 1.543.216.299.146 mengalami peningkatan dibandingkan tahun 2015 dengan total hutang pada tahun 2016 sebesar Rp 595.128.097.887 yang mengalami peningkatan dibandingkan tahun 2015. Hal ini menunjukkan semakin tinggi ukuran perusahaan maka total hutang yang terjadi di perusahaan semakin rendah namun kenyataannya semakin tinggi ukuran perusahaan maka total hutang akan semakin tinggi.

PT. Ekadharma International Tbk yang memiliki laba bersih setelah pajak pada tahun 2016 sebesar Rp 90.685.821.530 mengalami peningkatan dibandingkan tahun 2015 dengan total hutang pada tahun 2016 sebesar Rp 110.503.822.983 mengalami peningkatan dibandingkan tahun 2015. Laba bersih setelah pajak perusahaan yang meningkat seharusnya total hutang mengalami penurunan namun kenyataan laba bersih setelah pajak mengalami peningkatan yang diikuti dengan total hutang yang meningkat.

PT. Indocement Tunggal Prakarsa Tbk yang memiliki aktiva lancar pada tahun 2016 sebesar Rp 14.424.622.000.000 yang mengalami peningkatan dibandingkan tahun 2015 dengan total hutang pada tahun 2016 sebesar $\mathrm{Rp}$ 4.011.877.000.000 yang mengalami peningkatan dibandingkan tahun 2015. Aktiva lancar yang meningkat seharusnya dapat menurunkan total hutang namun kenyataan aktiva lancar yang meningkat dapat meningkatkan total hutang.

PT. Semen Indonesia (Persero) Tbk yang memiliki ekuitas pada tahun 2017 sebesar Rp 30.439.052.302.000 yang mengalami penurunan dibandingkan tahun 2016 dengan total hutang pada tahun 2017 sebesar Rp 18.524.450.664.000 yang mengalami peningkatan dibandingkan tahun 2016. Risiko bisnis yang menurun seharusnya total hutang menurun namun kenyataan risiko bisnis menurun mengakibatkan struktur modal meningkat.

\section{Tinjauan Pustaka}

\subsection{Pengaruh Net Profit Margin Terhadap Struktur Modal}

Sesuai dengan teori pecking order dalam pemilihan pendanaan, dimana pemilihan pendanaan berdasarkan biaya yang termurah. Artinya perusahaan lebih senang memenuhi kebutuhan dananya dengan pendanaan internal daripada eksternal. Perusahaan yang lebih profitable akan memerlukan pendanaan eksternal/utang yang lebih rendah. (Suripto, 2015) 
Husnan dan Pudjiastuti (2015:289) menyatakan perusahaan-perusahan yang sangat profitable biasanya akan mempunyai rasio hutang yang rendah, karena tidak memerlukan pendanaan eksternal. Teori ini menjelaskan mengapa diharapkan terdapat hubungan yang berkebalikan antara profitabilitas perusahaan dengan hutnag yang digunakan perusahaan. Semakin tinggi kemampuan perusahaan menghasilkan laba, semakin rendah rasio hutangnya dan kebalikannya.

Kamaludin dan Indriani (2012:305) menjelaskan bahwa resiko bisnis yang terkandung dalam operasi perusahaan, apabila ia tidak menggunakan hutang. Maka diartikan sebagai resiko yang berkaitan dengan ketidakpastian yang melekat tingkat pengembalian aktiva (ROA) suatu perusahaan di masa yang akan datang.

\subsection{Pengaruh Current Ratio Terhadap Struktur Modal}

Apabila rasio lancar rendah, maka dapat diartikan sebagai perusahaan yang memiliki modal yang rendah untuk membayar kewajibannya. Sebaliknya, apabila hasil pengukuran rasio tinggi, maka belum tentu dikatakan suatu perusahaan dalam kondisi baik (Kasmir, 2014).

Hutang jangka pendek lebih banyak risikonya dibanding hutang jangka panjang tetapi biayanya lebih rendah. Safety margin (marjin pengaman) merupakan pengurangan dari arus kas bersih yang diharapkan perusahaan dengan pembayaran atas bunganya. Marjin pengaman tergantung pada preferensi risiko pimpinan perusahaan. Keputusan atas komposisi jatuh tempo hutang perusahaan akan menentukan bagian aktiva lancar yang dibiayai oleh kewajiban lancar dan yang dibiayai oleh hutang jangka panjang. (Sudaryono, 2015:168).

Widati dan Nafisah (2017:20) berpendapat bahwa semakintinggi likuiditas maka hutangnya semakin kecil. Berdasarkan packing order theory bahwa lebih baik menggunakan dana internal terdahulu.

\subsection{Pengaruh Firm Size Terhadap Struktur Modal}

Ukuran perusahaan dengan penjualan yang besar menunjukkan prestasi perusahaan. Perusahaan yang besar akan lebih mudah mendapatkan akses ke sumber dana untuk memperoleh tambahan modal dengan utang (Sitanggang,2013:76).

Semakin besar ukuran suatu perusahaan, maka kecenderungan menggunakan modal asing juga semakin besar. Hal ini disebabkan karena perusahaan besar membutuhkan dana yang besar pula untuk menunjang operasionalnya, dan salah satu alternatif pemenuhannya adalah modal asing apabila modal sendiri tidak mencukupi. (Halim, 2015:125)

Menurut Sartono (2012:249) perusahaan besar yang sudah well-established akan lebih 
mudah memperoleh modal di pasar modal dibanding dengan perusahaan kecil. Karena kemudahan akses tersebut berarti perusahaan besar memiliki fleksibilitas yang lebih besar pula.

\subsection{Pengaruh Risiko Bisnis Terhadap Struktur Modal}

Risiko usaha atau tingkat risiko yang inheren dalam operasi perusahaan jika perusahaan tidak menggunakan utang. Makin besar risiko usaha perusahaan, maka makin rendah rasio utang optimalnya. (Bridgham dan Houston, 2012:155)

Penggunaan lebih banyak utang akan meningkatkan risiko yang ditanggung oleh para pemegang saham, missal risiko insolvabilitas, kenaikan suku bunga dan financial distress. (Ambarwati, 2010:2)

Risiko bisnis yang dimiliki perusahaan adalah tingkat risiko yang melekat pada operasi perusahaan apabila menggunakan hutang. Semakin tinggi risiko bisnis suatu perusahaan, semakin rendah rasio hutangnya. Perusahaan dengan risiko bisnis atau volatilitas aset yang tinggi mempunyai rasio hutang yang rendah. (Najmudin, 2011:315).

\subsection{Kerangka Konseptual}

Kerangka konseptual dapat digambarkan di bawah ini sebagai berikut :

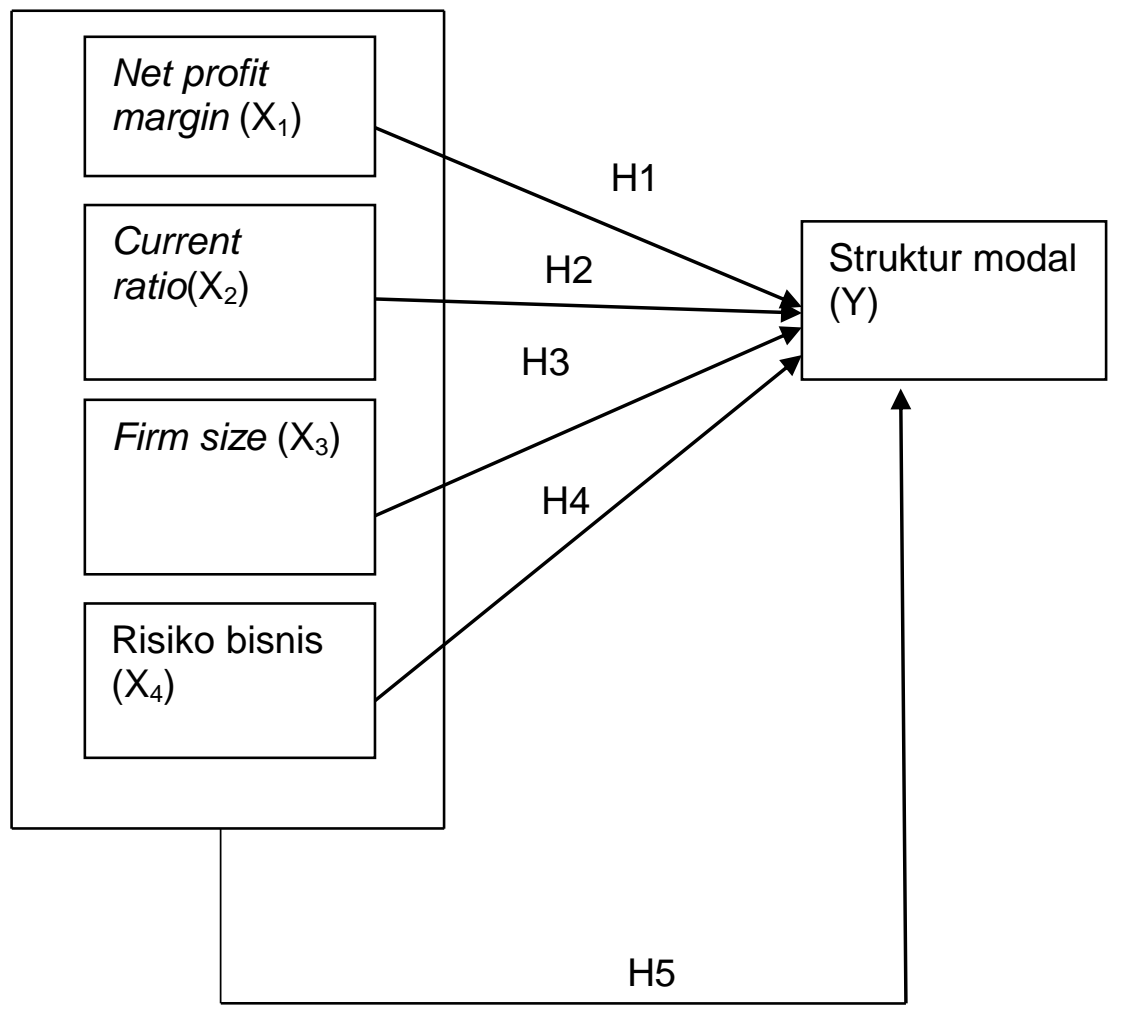

Gambar 2.1 Kerangka Konseptual 


\section{Metodologi Penelitian}

\subsection{Sampel dan Teknik Pengambilan Sampel}

Metode pengambilan sampel dalam penelitian ini dipilih dengan metode purposive sampling, yaitu pengambilan sampel berdasarkan kriteria tertentu.

\subsection{Operasional Variabel Penelitian}

\begin{tabular}{|c|c|c|c|c|}
\hline No. & Variabel & Definisi Variabel & Indikator & Skala \\
\hline 1. & $\begin{array}{l}\text { Net Profit Margin } \\
\text { (X1) }\end{array}$ & $\begin{array}{l}\text { Profit margin on sales } \\
\text { atau ratio profit margin } \\
\text { atau margin laba atas } \\
\text { penjualan merupakan } \\
\text { salah satu rasio yang } \\
\text { digunakan untuk } \\
\text { mengukur margin laba } \\
\text { atas penjualan. } \\
\text { Sumber: Murhardi } \\
\text { (2013:57) }\end{array}$ & $\begin{array}{l}\text { Net Profit Margin } \\
=\frac{\text { Laba Bersih Sesudah Pajak }}{\text { Penjualan }} \\
\begin{array}{c}\text { Sumber : Kodrat dan } \\
\text { Indonanjaya }(2014: 236) \\
\text { Current Assets } \\
\text { Current Liabilities }\end{array}\end{array}$ & Rasio \\
\hline 2. & Current Ratio (X2) & $\begin{array}{l}\text { Current ratio adalah } \\
\text { rasio yang menunjukkan } \\
\text { sejauh mana tagihan- } \\
\text { tagihan jangka pendek } \\
\text { dari para kreditor dapat } \\
\text { dipenuhi dengan aktiva } \\
\text { yang diharapkan akan } \\
\text { dikonversi menjadi uang } \\
\text { tunai dalam waktu dekat. } \\
\text { Sumber: Margaretha } \\
(2011: 25)\end{array}$ & $\begin{array}{l}\text { Current ratio } \\
=\frac{\text { Current Assets }}{\text { Current Liabilities }} \\
\text { Sumber : Fahmi (2017:59) }\end{array}$ & Rasio \\
\hline 3. & Firm Size (X3) & $\begin{array}{l}\text { Ukuran perusahaan } \\
\text { adalah suatu skala di } \\
\text { mana dapat } \\
\text { diklasifikasikan besar } \\
\text { kecilnya perusahaan } \\
\text { menurut berbagai cara } \\
\text { antara lain dengan total } \\
\text { aset, nilai pasar saham } \\
\text { dan lain-lain. } \\
\text { Sumber: Hery (2017:11) }\end{array}$ & $\begin{array}{l}\text { Ukuran Perusahaan = Ln } \\
\text { Total asset } \\
\text { Sumber : Rodoni dan Ali } \\
(2014: 193)\end{array}$ & Rasio \\
\hline 4. & Risiko Bisnis (X4) & $\begin{array}{l}\text { Risiko bisnis dalam } \\
\text { artian stand alone risk } \\
\text { adalah suatu fungsi dari } \\
\text { ketidakpastian yang } \\
\text { inheren didalam proyeksi } \\
\text { pengembalian atas } \\
\text { modal yang } \\
\text { diinvestasikan. } \\
\text { Sumber : Ambarwati } \\
(2010: 3)\end{array}$ & $\begin{array}{l}R O E=\frac{\text { Earning Af ter Tax }}{\text { Equity }} \\
\text { Sumber : Ambarwati (2010:4) }\end{array}$ & Rasio \\
\hline
\end{tabular}




\begin{tabular}{|c|c|c|c|c|}
\hline No. & Variabel & Definisi Variabel & Indikator & Skala \\
\hline 5. & Struktur Modal (Y) & $\begin{array}{l}\text { Struktur modal adalah } \\
\text { kombinasi atau } \\
\text { perimbangan antara } \\
\text { utang dan modal sendiri } \\
\text { (saham preferen dan } \\
\text { saham biasa) yang } \\
\text { digunakan perusahaan } \\
\text { untuk merencanakan } \\
\text { mendapatkan modal. } \\
\text { Sumber: Ambarwati } \\
\text { (2010:1) }\end{array}$ & $\begin{array}{c}D E R=\frac{\text { Total Debt }}{\text { Equity }} \\
\text { Sumber : Kasmir (2014:158) }\end{array}$ & Rasio \\
\hline
\end{tabular}

\subsection{Model Analisis Data Penelitian}

3.3.1. Model Analisis Data

Penelitian ini menggunakan analisis regresi linear berganda. Model regresi linear berganda yang digunakan adalah sebagai berikut :

$\mathrm{Y}=\mathrm{a}+\mathrm{b} 1 \mathrm{X} 1+\mathrm{b} 2 \mathrm{X} 2+\mathrm{b} 3 \mathrm{X} 3+\mathrm{b} 4 \mathrm{X} 4+\mathrm{e}$

Keterangan :

Y $\quad$ : Struktur Modal

a : konstanta

X1 :Net Profit Margin

X2 :Current Ratio

X3 : Firm Size

X4 : Risiko Bisnis

b1,2,3,4 : besaran koefisien regresi dari masing-masing variabel

e :error

\subsubsection{Koefisien Determinasi}

Menurut Ghozali (2018:97), Koefisien determinasi ditujukan untuk mengukur seberapa jauh kemampuan model dalam menerangkan variasi terikat.

\subsubsection{Pengujian Hipotesis Secara Simultan (Uji F)}

Menurut Sanusi (2013:137-138), uji F yang signifikan menunjukkan bahwa variasi terikat dijelaskan sekian persen oleh variabel bebas secara bersama-sama adalah benar-benar nyata dan bukan terjadi karena kebetulan. 


\subsubsection{Pengujian Hipotesis Secara Parsial (Uji t)}

Menurut Sanusi (2013:138), uji signifikasikan terhadap masing-masing koefisien regresi diperlukan untuk mengetahui signifikan tidaknya pengaruh dari masing-masing variabel bebas $(\mathrm{X})$ terhadap variabel terikat $(\mathrm{Y})$.

\section{Analisis dan Pembahasan}

Tabel 4.1.1. Statistik Deskriptif

\begin{tabular}{|l|r|r|r|r|r|}
\hline & N & \multicolumn{1}{|c|}{ Min. } & \multicolumn{1}{c|}{ Max. } & \multicolumn{1}{c|}{ Mean } & $\begin{array}{c}\text { Std. } \\
\text { Deviation }\end{array}$ \\
\hline NPM & 124 &, 00 &, 27 &, 0683 &, 06114 \\
\hline CR & 124 &, 79 & 15,16 & 2,8835 & 2,80975 \\
\hline UK & 124 & 25,62 & 32,27 & 28,579 & 1,69506 \\
\hline ROE & 124 &, 00 &, 29 &, 0983 &, 06849 \\
\hline DER & 124 &, 07 & 7,99 & 1,0724 & 1,18725 \\
\hline $\begin{array}{l}\text { Valid N } \\
\text { (listwise) }\end{array}$ & 124 & & & & \\
\hline
\end{tabular}

Berdasarkan tabel tersebut menunjukkan nilai minimum, nilai maksimum, nilai rata-rata (mean), dan standar deviasi dari variabel net profit margin, current ratio, firm size, risiko bisnis dan struktur modal dengan rincian sebagai berikut:

1. Variabel net profit margin memiliki jumlah sampel sebanyak 124 , dengan nilai minimum 0,00 pada PT. Tembaga Mulia Semanan Tbk tahun 2015, PT. Pabrik Kertas Tjiwi Kimia Tbk tahun 2015, PT. Steel Pine Industry of Indonesia Tbk tahun 2017 dan nilai maksimum 0,27 pada PT. Semen Baturaja Persero Tbk tahun 2014 sedangkan nilai rata-rata (mean) 0,0683 dengan standar deviasi 0,06114 .

2. Variabel current ratio tetap memiliki jumlah sampel sebanyak 124, dengan nilai minimum0,79 pada PT. Tembaga Mulia Semanan Tbk tahun 2014 dan nilai maksimum 15,16 pada PT. Duta Pertiwi Nusantara Tbk tahun 2016 sedangkan nilai rata-rata (mean) 2,8835 dengan standar deviasi 2,80975.

3. Variabel firm size memiliki jumlah sampel sebanyak 124 , dengan nilai minimum 25,62 pada PT. Lionmesh Prima Tbk tahun 2015 dan nilai maksimum 32,27 pada PT. Indah Kiat Pulp \& Paper Tbk tahun 2017sedangkan nilai rata-rata (mean) 28,5794 dengan standar deviasi $1,69506$.

4. Variabel risiko bisnis memiliki jumlah sampel sebanyak 124, dengan nilai minimum 0,00 pada PT. Pabrik Kertas Tjiwi Kimia Tbk tahun 2015 dan nilai maksimum 0,29 pada PT. Arwana Citramulia Tbk tahun 2014sedangkan nilai rata-rata (mean) 0,0983 dengan standar deviasi 0,06849 . 
5. Variabel struktur modal memiliki jumlah sampel sebanyak 124 , dengan nilai minimum 0,07 pada PT. Semen Baturaja Persero Tbk tahun 2014 dan nilai maksimum 7,99 pada PT. Tembaga Mulia Semanan Tbk tahun 2014sedangkan nilai rata-rata (mean) 1,0724 dengan standar deviasi 1,18725 .

\subsection{Hasil Analisis Data}

\subsubsection{Analisis Regresi Linier Berganda}

Tabel 4.1.2. Hasil Analisis Regresi Linier Berganda

\begin{tabular}{|c|c|c|c|c|c|c|}
\hline \multicolumn{7}{|c|}{ Coefficients $^{a}$} \\
\hline \multirow{2}{*}{\multicolumn{2}{|c|}{ Model }} & \multicolumn{2}{|c|}{$\begin{array}{l}\text { Unstandardized } \\
\text { Coefficients }\end{array}$} & \multirow{2}{*}{$\begin{array}{c}\begin{array}{c}\text { Standardized } \\
\text { Coefficients }\end{array} \\
\text { Beta }\end{array}$} & \multirow[t]{2}{*}{$\mathrm{t}$} & \multirow[t]{2}{*}{ Sig. } \\
\hline & & $\mathrm{B}$ & Std. Error & & & \\
\hline \multirow[t]{5}{*}{1} & $\begin{array}{l}\text { (Consta } \\
\text { nt) }\end{array}$ & $-8,645$ & 2,715 & & $-3,184$ & ,002 \\
\hline & $\begin{array}{l}\text { Ln_NP } \\
M\end{array}$ &,- 593 & ,078 &,- 571 & $-7,647$ & ,000 \\
\hline & Ln_CR &,- 760 & 083 &,- 551 & $-9,192$ &, 000 \\
\hline & Ln UK & 2,468 & 779 & 150 & 3,167 &, 002 \\
\hline & Ln ROE &, 482 & 067 & 423 & 7,220 &, 000 \\
\hline
\end{tabular}

a. Dependent Variable: Ln_DER

Berdasarkan tabel di atas diperoleh rumus regresi sebagai berikut:

Ln_Struktur Modal $=-8,645-0,593$ Ln_NPM - 0,760 Ln_CR + 2,468 Ln_UK + 0,482 Ln_ROE

Hasil interpretasi dari regresi tersebut adalah sebagai berikut:

1. Nilai a sebesar $-8,645$ artinya jika variabel net profit margin, current ratio, firm size, risiko bisnis dianggap konstan, maka struktur modaladalah sebesar -8,645.

2. Nilai koefisien net profit margin $\left(X_{1}\right)$ adalah0,593. Ini menunjukkan bahwa setiap peningkatan net profit margin satu kali maka struktur modalakan mengalami penurunan sebesar 0,593.

3. Nilai koefisien current ratio $\left(X_{2}\right)$ sebesar 0,760 . Ini menunjukkan bahwa setiap peningkatancurrent ratio satu kali maka struktur modal akan mengalami penurunan sebesar 0,760 .

4. Nilai koefisien firm size $\left(\mathrm{X}_{3}\right)$ sebesar 2,468 . Ini menunjukkan bahwa setiap peningkatanfirm size satu kali maka struktur modalakan mengalami peningkatan sebesar 2,468.

5. Nilai koefisien risiko bisnis $\left(\mathrm{X}_{4}\right)$ sebesar 0,482. Ini menunjukkan bahwa setiap peningkatanrisiko bisnis satu kali maka struktur modalakan mengalami peningkatan sebesar 0,482 . 


\subsubsection{Koefisien Determinasi $\left(R^{2}\right)$}

Tabel 4.1.3. Koefisien Determinasi

\begin{tabular}{|l|c|r|r|r|}
\hline \multicolumn{5}{|c|}{ Model Summary $^{\mathbf{b}}$} \\
\hline Model & $\mathrm{R}$ & $\mathrm{R}$ Square & $\begin{array}{c}\text { Adjusted R } \\
\text { Square }\end{array}$ & $\begin{array}{c}\text { Std. Error of } \\
\text { the Estimate }\end{array}$ \\
\hline 1 &, $911^{\mathrm{a}}$ &, 830 &, 824 &, 40753 \\
\hline a. Predictors: (Constant), Ln_ROE, Ln_UK, Ln_CR, Ln_NPM \\
\hline
\end{tabular}

Nilai adjusted $R$ Square $\left(R^{2}\right)$ koefisien determinasi sebesar 0,824 atau sama dengan $82,4 \%$ dipengaruhi oleh variabel independen terhadap variabel dependen sedangkan sisanya $17,6 \%$ dipengaruhi variabel lain seperti seperti struktur aktiva, stabilitas penjualan dna kebijakan dividen.

\subsubsection{Pengujian Hipotesis Secara Simultan (Uji Statistik F)}

Tabel 4.1.4. Hasil Uji Statistik F

\begin{tabular}{|c|c|c|c|c|c|c|}
\hline \multicolumn{7}{|c|}{ ANOVA $^{a}$} \\
\hline \multicolumn{2}{|c|}{ Model } & $\begin{array}{l}\text { Sum of } \\
\text { Squares }\end{array}$ & df & $\begin{array}{c}\text { Mean } \\
\text { Square }\end{array}$ & $\mathrm{F}$ & Sig. \\
\hline \multirow[t]{3}{*}{1} & Regression & 94,218 & 4 & 23,555 & 141,824 &, $000^{b}$ \\
\hline & Residual & 19,266 & 116 &, 166 & & \\
\hline & Total & 113,484 & 120 & & & \\
\hline
\end{tabular}

Bisa dilihat hasil $F_{\text {hitung }}$ adalah sebesar 141,824dengan nilai signifikan 0,000, sedangkan $F_{\text {tabel }}(124-5=119)$ adalah sebesar 2,45 maka kesimpulannya adalah $F_{\text {hitung }}>F_{\text {tabel }}$ yaitu 141,824> 2,45 sehingga keputusannya adalah Ho ditolak dan $\mathrm{Ha}$ diterima, artinya variabel Net profit margin, current ratio, firm size, risiko bisnis berpengaruh dan signifikan terhadap struktur modal pada perusahaan industri dasar dan kimia di Bursa Efek Indonesia Periode 2014-2017.

\subsubsection{Pengujian Hipotesis Secara Parsial (Uji Statistik t)}

1. Net profit margin mempunyai nilai $t_{\text {hitung }}$ adalah sebesar $-7,647$ dengan nilai signifikan $0,000<0,05$, sedangkan nilai $t_{\text {tabel }}(124-4=120)$ adalah sebesar 1,979 sehingga kesimpulannya adalah-t hitung $_{<-t_{\text {tabel }}}$ yaitu $-7,647<-1,979$ maka keputusannya adalah Ho diterima danH $_{\mathrm{a}}$ ditolak, artinya variabel Net profit margin berpengaruh dan tidak signifikan terhadap struktur modal pada perusahaan industri dasar dan kimia di Bursa Efek Indonesia Periode 2014-2017. 
2. Current ratiomempunyai nilai $t_{\text {hitung }}-9,192$ dengan nilai signifikan $0,000<0,05$, sedangkan $t_{\text {tabel }}$ adalah sebesar 1,979 maka kesimpulannya adalah $-t_{\text {hitung }}<-t_{\text {tabel }}$ yaitu $-9,192<-1,979$ sehingga keputusannya adalah Ho diterimadan $\mathrm{H}_{\mathrm{a}}$ ditolak, artinya variabel Current ratio berpengaruh dan tidak signifikan terhadap struktur modal pada perusahaan industri dasar dan kimia di Bursa Efek Indonesia Periode 2014-2017.

3. Firm size mempunyai nilai $t_{\text {hitung }} 3,167$ dengan nilai signifikan $0,002<0,05$, sedangkan $t_{\text {tabel }}$ adalah sebesar 1,979 maka kesimpulannya adalah $t_{\text {hitung }}>t_{\text {tabel }}$ yaitu 3,167> 1,979 sehingga keputusannya adalah $\mathrm{Ho}$ dan diterima $\mathrm{H}_{\mathrm{a}}$ ditolak, artinya variabel Firm size berpengaruh dan signifikan terhadap struktur modal pada perusahaan industri dasar dan kimia di Bursa Efek Indonesia Periode 2014-2017.

4. Risiko bisnis mempunyai nilai $t_{\text {hitung }} 7,220$ dengan nilai signifikan $0,000<0,05$, sedangkan $t_{\text {tabel }}$ adalah sebesar 1,979 maka kesimpulannya adalah $t_{\text {hitung }}>t_{\text {tabel }}$ yaitu 7,220>1,979 sehingga keputusannya adalah $\mathrm{Ho}$ dan diterima $\mathrm{H}_{\mathrm{a}}$ ditolak, artinya variabel Risiko bisnis berpengaruh dan signifikan terhadap struktur modal pada perusahaan industri dasar dan kimia di Bursa Efek Indonesia Periode 2014-2017.

Tabel 4.1.5. Hasil Uji Statistik $\mathbf{t}$

\begin{tabular}{|c|c|c|c|c|c|c|}
\hline \multicolumn{7}{|c|}{ Coefficients $^{\mathrm{a}}$} \\
\hline \multirow{2}{*}{\multicolumn{2}{|c|}{ Model }} & \multicolumn{2}{|c|}{$\begin{array}{l}\text { Unstandardized } \\
\text { Coefficients }\end{array}$} & \multirow{2}{*}{$\begin{array}{c}\text { Standardized } \\
\text { Coefficients } \\
\text { Beta }\end{array}$} & \multirow[b]{2}{*}{$\mathrm{t}$} & \multirow[b]{2}{*}{ Siq. } \\
\hline & & $\mathrm{B}$ & Std. Error & & & \\
\hline \multirow[t]{5}{*}{1} & (Constant) & $-8,645$ & 2,715 & & $-3,184$ &, 002 \\
\hline & Ln NPM &,- 593 & ,078 &,- 571 & $-7,647$ &, 000 \\
\hline & Ln_CR &,- 760 & 083 &,- 551 & $-9,192$ &, 000 \\
\hline & Ln_UK & 2,468 & ,779 &, 150 & 3,167 &, 002 \\
\hline & Ln ROE &, 482 &, 067 & 423 & 7,220 &, 000 \\
\hline
\end{tabular}

Hasil pengujian statistik secara parsial sebagai berikut :

Net profit margin berpengaruh dan tidak signifikan terhadap struktur modal pada perusahaan industri dasar dan kimia di Bursa Efek Indonesia Periode 2014-2017.

Hasil penelitian ini sesuai dengan teori Suripto (2015:8-9) sesuai dengan teori pecking order dalam pemilihan pendanaan, dimana pemilihan pendanaan berdasarkan biaya yang termurah. Artinya perusahaan lebih senang memenuhi kebutuhan dananya dengan pendanaan internal daripada eksternal. Perusahaan yang lebih profitable akan memerlukan pendanaan eksternal/utang yang lebih rendah.

Hasil penelitian ini sejalan dengan penelitian yang dilakukan Sari dan Ardini (2017) yang menyatakan, profitabilitas memiliki pengaruh negatif signifikan terhadap struktur modal

Current ratio berpengaruh dan tidak signifikan terhadap struktur modal pada perusahaan industri dasar dan kimia di Bursa Efek Indonesia Periode 2014-2017. 
Hasil penelitian ini sesuai dengan teori Kasmir (2014:135) apabila rasio lancar rendah dapat dikatakan bahwa perusahaan kurang modal untuk membayar utang. Namun, apabila hasil pengukuran rasio tinggi, belum tentu kondisi perusahaan sedang baik. Hal ini dapat saja terjadi karena kas tidak digunakan sebaik mungkin.

Hasil penelitian ini sejalan dengan penelitian yang dilakukan Hudan, Isyuwardhana dan Triyanto (2016) yang menyatakan, likuiditas berpengaruh negatif signifikan Terhadap Struktur Modal (Studi Pada Perusahaan Pertambangan Sektor Batubara yang Terdaftar di Bursa Efek Indonesia Tahun 2011-2015).

Firm size berpengaruh dan signifikan terhadap struktur modal pada perusahaan industri dasar dan kimia di Bursa Efek Indonesia Periode 2014-2017

Hasil penelitian ini sesuai dengan teori Halim (2015 : 125), semakin besar ukuran suatu perusahaan, maka kecenderungan menggunakan modal asing juga semakin besar. Hal ini disebabkan karena perusahaan besar membutuhkan dana yang besar pula untuk menunjang operasionalnya, dan salah satu alternatif pemenuhannya adalah modal asing apabila modal sendiri tidak mencukupi.

Hasil penelitian ini sejalan dengan penelitian yang dilakukan Hudan, Isyuwardhana dan Triyanto (2016) yang menyatakan, ukuran perusahaan berpengaruh negatif signifikan Terhadap Struktur Modal (Studi Pada Perusahaan Pertambangan Sektor Batubara yang Terdaftar di Bursa Efek Indonesia Tahun 2011-2015).

Risiko bisnis berpengaruh dan signifikan terhadap struktur modal pada perusahaan industri dasar dan kimia di Bursa Efek Indonesia Periode 2014-2017.

Hasil penelitian ini sesuai dengan teori Brigham dan Houston (2012:155) risiko usaha atau tingkat risiko yang inheren dalam operasi perusahaan jika perusahaan tidak menggunakan utang. Makin besar risiko usaha perusahaan, maka makin rendah rasio utang optimalnya.

Hasil penelitian ini sejalan dengan penelitian yang dilakukan Sari dan Ardini (2017) yang menyatakan, Risiko bisnis memiliki pengaruh negatif signifikan terhadap struktur modal.

\section{Kesimpulan dan Saran}

\subsection{Kesimpulan}

Berdasarkan pada hasil penelitian, maka dapat ditarik beberapa kesimpulan sebagai berikut:

1. Net profit margin berpengaruh dan tidak signifikan terhadap struktur modal pada perusahaan industri dasar dan kimia di Bursa Efek Indonesia Periode 2014-2017. 
2. Current ratio berpengaruh dan tidak signifikan terhadap struktur modal pada perusahaan industri dasar dan kimia di Bursa Efek Indonesia Periode 2014-2017.

3. Firm size berpengaruh dan signifikan terhadap struktur modal pada perusahaan industri dasar dan kimia di Bursa Efek Indonesia Periode 2014-2017.

4. Risiko bisnis berpengaruh dan signifikan terhadap struktur modal pada perusahaan industri dasar dan kimia di Bursa Efek Indonesia Periode 2014-2017.

5. Net profit margin, current ratio, firm size, risiko bisnis berpengaruh dan signifikan terhadap struktur modal pada perusahaan industri dasar dan kimia di Bursa Efek Indonesia Periode 2014-2017.

\subsection{Saran}

Berdasarkan hasil penelitian yang telah peneliti kemukakan, saran-saran yang dapat peneliti berikan adalah sebagai berikut:

1. Bagi Investor, sebaiknya hasil penelitian ini berguna bagi para investor agar dapat mengetahui struktur modal yang dimiliki perusahaan.

2. Bagi peneliti selanjutnya dapat menggunakan hasil penelitian ini sebagai bahan acuan dalam menyusun karya ilmiah empiris yang berhubungan dengan pengaruh net profit margin, current ratio, firm size, risiko bisnis terhadap struktur modal.

3. Bagi Universitas Prima Indonesia, sebaiknya hasil penelitian ini berguna bagi para mahasiswa-mahasiswi.

\section{Daftar Pustaka}

Ambarwati, Sri Dwi Ari. 2010. Manajemen Keuangan Lanjut. Edisi Pertama. Yogyakarta : Penerbit Graha IImu

Brigham, Eugene F. \& Joel F. Houston. 2011. Dasar-dasar Manajemen Keuangan. Buku 2. Jakarta : Penerbit Salemba Empat.

Halim, Abdul. 2015. Manajemen Keuangan Bisnis Konsep dan Aplikasinya. Jakarta : Penerbit Mitra Wacana Media

Hery. 2017. Kajian Riset Akuntansi Mengulas Berbagai Hasil Penelitian Terkini Dalam Bidang Akuntansi dan Keuangan. Jakarta : Penerbit PT Grasindo.

Hery. 2017. Teori Akuntansi Pendekatan Konsep dan Analisis. Jakarta : Penerbit PT Grasindo. Hudan, Isynuwardhana dan Triyanto. 2018. Pengaruh Profitabilitas, Likuiditas Dan Ukuran Perusahaan Terhadap Struktur Modal(Studi Pada Perusahaan Pertambangan Sektor Batubara Yang Terdaftar Di Bursa Efek Indonesia Tahun 2011-2015). e- 
Proceeding of Management : Vol.3, No.2 Agustus 2016. Universitas Telkom.

Husnan, Suad \& Pudjiastuti, Enny. 2015. Dasar-dasar Manajemen Keuangan. Edisi Ketujuh. Yogyakarta : UPP STIM YKPN

Kamaludin \& Indriani, Rini. 2012. Manajemen Keuangan. Penerbit CV. Mandar Maju. Bandung Kasmir. 2014. .Analisis Laporan Keuangan. Cetakan Keempat.Jakarta : Penerbit Rajagrafindo Persada.

Margaretha, Farah. 2011. Manajemen Keuangan Untuk Manajer Non Keuangan. Jakarta : Penerbit Erlangga.

Murhadi, Werner. 2013. Analisis Laporan Keuangan Proyeksi dan Valuasi Saham. Jakarta : Penerbit Salemba Empat.

Najmudin. 2011. Manajemen Keuangan dan Aktualisasi Syariyyah Modern. Yogyakarta : Penerbit Andi.

Sitanggang. 2013. Manajemen Keuangan Perusahaan Lanjutan. Jakarta : Penerbit Mitra Wacana Media.

Sudaryono. 2015. Pengantar Bisnis Teori \& Contoh Kasus. Yogyakarta : Penerbit Andi.

Sugiyono. 2012. Metode Penelitian Bisnis. Cetakan Keenam Belas. Bandung: Penerbit Alfabeta.

Suripto. 2015. Manajemen Keuangan Strategi Penciptaan Nilai Perusahaan Melalui Pendekatan Economic Value Added. Jakarta : Penerbit Graha IImu.

Widati, Listyorini Wahyu dan Siti Nafisah. 2017. Analisis Pengaruh Struktur Aset, Risiko Bisnis, Pajak Dan Likuiditas Terhadap Keputusan Pendanaan Pada Perusahaan Manufaktur Yang Terdaftar Di Bursa Efek Indonesia. Dinamika Akuntansi, Keuangan dan Perbankan, Mei 2017, Hal: 19-27. Universitas Stikubank Semarang. 